Article

\title{
New Natural Oxygenated Sesquiterpenes and Chemical Composition of Leaf Essential Oil from Ivoirian Isolona dewevrei (De Wild. \& T. Durand) Engl. \& Diels
}

\author{
Didjour Albert Kambiré ${ }^{1}{ }^{1}$, Jean Brice Boti ${ }^{1}$, Thierry Acafou Yapi ${ }^{1}$, Zana Adama Ouattara ${ }^{2}$, \\ Ange Bighelli ${ }^{3}$, Joseph Casanova ${ }^{3}$ and Félix Tomi ${ }^{3, *(D)}$ \\ 1 Laboratoire de Constitution et Réaction de la Matière, UFR-SSMT, Université Félix Houphouët-Boigny, \\ Abidjan 01 BP V34, Ivory Coast; dakambire@gmail.com (D.A.K.); jeanbriceboti@hotmail.fr (J.B.B.); \\ acafouth@yahoo.fr (T.A.Y.) \\ 2 Laboratoire de Chimie Bio-Organique et de Substances Naturelles, UFR SFA, Université Nangui Abrogoua, \\ Abidjan 02 BP 801, Ivory Coast; zana1504@yahoo.fr \\ 3 Laboratoire Sciences Pour l'Environnement, Equipe Chimie et Biomasse, Université de Corse-CNRS, \\ UMR 6134 SPE, Route des Sanguinaires, 20000 Ajaccio, France; bighelli@univ-corse.fr (A.B.); \\ joseph.casanova@wanadoo.fr (J.C.) \\ * Correspondence: felix.tomi@univ-corse.fr
}

Received: 12 November 2020; Accepted: 27 November 2020; Published: 29 November 2020

\begin{abstract}
This study aimed to investigate the chemical composition of the leaf essential oil from Ivoirian Isolona dewevrei. A combination of chromatographic and spectroscopic techniques (GC(RI), GC-MS and ${ }^{13} \mathrm{C}-\mathrm{NMR}$ ) was used to analyze two oil samples (S1 and S2). Detailed analysis by repetitive column chromatography (CC) of essential oil sample S2 was performed, leading to the isolation of four compounds. Their structures were elucidated by QTOF-MS, 1D and 2D-NMR as $(10 \beta \mathrm{H})-1 \beta, 8 \beta$-oxido-cadin-4-ene (38), 4-methylene-( $7 \alpha \mathrm{H})$-germacra-1(10),5-dien-8 $\beta$-ol (cis-germacrene D-8-ol) (52), 4-methylene- $(7 \alpha \mathrm{H})$-germacra-1(10),5-dien-8 $\alpha$-ol (trans-germacrene D-8-ol) (53) and cadina-1(10),4-dien-8 $\beta$-ol (56). Compounds 38, 52 and 53 are new, whereas NMR data of $\mathbf{5 6}$ are reported for the first time. Lastly, 57 constituents accounting for $95.5 \%$ (S1) and $97.1 \%$ (S2) of the whole compositions were identified. Samples S1 and S2 were dominated by germacrene $\mathrm{D}$ (23.6 and $20.5 \%$, respectively), followed by germacrene D-8-one ( 8.9 and $8.7 \%),(10 \beta \mathrm{H})-1 \beta, 8 \beta$-oxido-cadin-4-ene (7.3 and 8.7), 4-methylene- $(7 \alpha \mathrm{H})$-germacra-1(10),5-dien-8 $\beta$-ol (7.8 and $7.4 \%$ ) and cadina-1(10),4-dien- $8 \beta$-ol (7.6 and 7.2\%). Leaves from I. dewerrei produced sesquiterpene-rich essential oil with an original chemical composition, involving various compounds reported for the first time among the main components. Integrated analysis by GC(RI), GC-MS and ${ }^{13} \mathrm{C}-\mathrm{NMR}$ appeared fruitful for the knowledge of such a complex essential oil.
\end{abstract}

Keywords: Isolona dewevrei; leaf essential oil; $(10 \beta \mathrm{H})-1 \beta, 8 \beta$-oxido-cadin-4-ene; cis-germacrene D-8-ol; trans-germacrene D-8-ol; cadina-1(10),4-dien-8 $\beta$-ol

\section{Introduction}

Isolona dewevrei (De Wild. \& T. Durand) Engl. \& Diels (synonym: Monodora dewevrei De Wild. \& T. Durand; genus Isolona Engl., Annonaceae) is an evergreen shrub or a tree that can reach $15 \mathrm{~m}$ in height. Leaves are narrowly obovate to obovate or elliptic to narrowly elliptic, $10-17 \mathrm{~cm}$ long and 4-7 cm wide, with acuminated apex. The inflorescences appear on leafy branches and sometimes on older ones, whereas the fruits are ovoid (6-7 cm long, $4-5 \mathrm{~cm}$ in diameter), smooth but 
very finely ribbed, glabrous, green and become yellow at maturity [1]. The genus Isolona consists of 20 species widely distributed in the tropical rain forests of West and Central Africa, and Madagascar. Five species of this genus grow wild in Côte d'Ivoire: Isolona campanulata, I. cooperi, I. deightonii, I. soubreana and I. dewevrei. I. cooperi and I. campanulata are used in Ivorian herbal medicine to treat bronchial ailments, skin diseases, hematuria, infertility and to facilitate childbirth [1,2].

Reported studies carried out on solvent extracts of I. campanulata and I. cooperi have led to the isolation and identification of various alkaloids, sterols and sesquiterpenes [3-5]. Concerning the volatile constituents of Isolona species, the chemical compositions of essential oils from I. cooperi and I. campanulata were determined. The main constituents of leaf and stem bark oils from I. cooperi were (Z)- $\beta$-ocimene and $\gamma$-terpinene, while the composition of root bark oil was dominated by 5 -isopentenylindole and (E)- $\beta$-caryophyllene [6]. The leaf oil from I. campanulata was rich in sesquiterpenes and its composition was dominated either by eudesm-5-en-11-ol or by (E)- $\beta$-caryophyllene and $\alpha$-humulene [7]. In previous works, we investigated and reported for the first time the chemical compositions of leaf, root and stem bark essential oils from I. dewevrei, dominated by germacrene B/germacrene $\mathrm{D}$ and by cyperene, respectively. From the leaf oil, four new compounds were isolated and characterized as 6,12-oxido-germacra-1(10),4,6,11(12)-tetraene, ( $5 \alpha \mathrm{H}, 10 \beta \mathrm{Me})-6,12$-oxido-elema-1,3,6,11(12)-tetraene, germacra-1(10),4,7(11)-trien-6,12- $\gamma$-lactone and $(1 \beta \mathrm{H}, 5 \beta \mathrm{H})-6,12$-oxido-guaia-6,10(14),11(12)-trien-4 $\alpha$-ol [8]. The structure of germacrene D-8-one, another new natural compound, was also elucidated after isolation from the stem bark essential oil of the plant [9].

Continuing the chemical characterization of essential oils of aromatic and medicinal plants from Côte d'Ivoire [10-14], we now report on the chemical composition of the leaf essential oil from I. dewevrei, along with isolation and structure elucidation of three new natural sesquiterpenes as well as description of NMR data of a fourth sesquiterpene.

\section{Results and Discussion}

Two leaf essential oil samples (S1 and S2) from I. dewevrei growing wild in Côte d'Ivoire were obtained by hydrodistillation of fresh leaves and the yields calculated on a weight basis $(w / w)$ were 0.105 and $0.121 \%$, respectively. The oil samples were first analyzed by a combination of GC(RI), GC-MS and ${ }^{13} \mathrm{C}-\mathrm{NMR}$, following a computerized method developed at the University of Corsica. This method allowed identification of components present at a content as low as $0.4-0.5 \%$ and compiled in our laboratory-made ${ }^{13}$ C-NMR spectral data library $[15,16]$.

Although various constituents were identified by the mean of the three techniques, several others, some of which were present at appreciable amounts, remained unidentified. Special attention was paid to four of them that belong to the oxygenated sesquiterpene family, according to their apolar and polar retention indices: compounds 38 (retention indices measured on apolar and polar capillary column, respectively $(\mathrm{RIa} / \mathrm{RIp})=1534 / 1853 ; 7.3$ and 8.7\%), 52 and $53(\mathrm{RIa} / \mathrm{RIp}=1657 / 2355 ; 10.4$ and 9.9\%) and $56(\mathrm{RIa} / \mathrm{RIp}=1676 / 2276 ; 7.6$ and 7.2\%). Therefore, essential oil sample S2, which had a higher amount $(2.9 \mathrm{~g})$ and contained the four unidentified compounds, was subjected to repetitive column chromatography (CC) in order to perform structural elucidation. In parallel, analysis of CC fractions by GC(RI), GC-MS and ${ }^{13} \mathrm{C}-\mathrm{NMR}$ led to the identification of several minor components.

\subsection{Structure Elucidation of Unidentified Compounds}

\subsubsection{Structure Elucidation of Compound 38}

Compound 38 was obtained with a great degree of purity (GC: 98.7\%) in the sub-fraction F4.3.1 (15 mg). The exact mass measured by GC-QTOF-MS was $220.1821 \mathrm{~g} / \mathrm{mol}$, corresponding to the empirical formula $\mathrm{C}_{15} \mathrm{H}_{24} \mathrm{O}$ (calculated mass $=220.1822 \mathrm{~g} / \mathrm{mol}$ ). The ${ }^{1} \mathrm{H}-\mathrm{NMR},{ }^{13} \mathrm{C}-\mathrm{NMR}$ and DEPT spectra were in agreement with the $\mathrm{C}_{15} \mathrm{H}_{24} \mathrm{O}$ formula, which involved four unsaturation degrees (Table 1) (Supplementary Materials, Figures S1-S8). 
Table 1. NMR data of compound 38.

\begin{tabular}{|c|c|c|c|c|c|c|c|}
\hline \multicolumn{8}{|c|}{ Compound 38} \\
\hline $\mathrm{C}$ & $\begin{array}{l}\delta^{13} \mathrm{C} \\
(\mathrm{ppm})\end{array}$ & DEPT & $\begin{array}{c}\delta^{1} \mathbf{H} \\
(\mathrm{ppm})\end{array}$ & $\begin{array}{l}\text { Multiplicity } \\
(\mathrm{J}(\mathrm{Hz}))\end{array}$ & $\begin{array}{c}\text { COSY } \\
{ }^{1} \mathbf{H}-{ }^{1} \mathbf{H}\end{array}$ & $\mathrm{HMBC} \mathrm{H} \rightarrow \mathrm{C}$ & $\begin{array}{c}\text { NOESY } \\
{ }^{1} \mathbf{H}-{ }^{1} \mathbf{H}\end{array}$ \\
\hline 1 & 86.63 & $\mathrm{C}$ & - & - & - & - & - \\
\hline \multirow{2}{*}{2} & \multirow{2}{*}{30.71} & \multirow{2}{*}{$\mathrm{CH}_{2}$} & a 2.15 & $\mathrm{~m}$ & $2 b, 3 a, 3 b$ & $1,3,4,6,10$ & $2 b, 3 a$ \\
\hline & & & b 2.29 & $\mathrm{~m}$ & $2 a, 3 a, 3 b$ & $1,3,4,6,10$ & $2 a, 3 b$ \\
\hline \multirow{2}{*}{3} & \multirow{2}{*}{30.13} & \multirow{2}{*}{$\mathrm{CH}_{2}$} & a 2.00 & $\mathrm{~m}$ & $2 a, 2 b, 3 b$ & $1,2,4,5,15$ & $2 a, 3 b$ \\
\hline & & & b 2.17 & $\mathrm{~m}$ & $2 b, 3 a, 3 b$ & $1,2,4,5,15$ & $2 b, 3 a, 15$ \\
\hline 4 & 133.78 & $\mathrm{C}$ & - & - & - & - & - \\
\hline 5 & 122.89 & $\mathrm{CH}$ & 5.57 & quint (1.5) & 6 & $1,4,6,7,15$ & $6,13,15$ \\
\hline 6 & 51.98 & $\mathrm{CH}$ & 2.25 & $\mathrm{~m}$ & 5,7 & $1,2,4,5,7,10$ & $5,11,13$ \\
\hline 7 & 54.01 & $\mathrm{CH}$ & 1.16 & $\mathrm{t}(9.3)$ & $6,8,11$ & $5,6,8,11,12,13$ & $2 b, 8,9 a, 14$ \\
\hline 8 & 81.75 & $\mathrm{CH}$ & 4.27 & $\mathrm{~d}(5.2)$ & $7,9 a, 9 b$ & $6,7,9,10,11$ & $7,9 a, 14$ \\
\hline \multirow{2}{*}{9} & \multirow{2}{*}{43.42} & \multirow{2}{*}{$\mathrm{CH}_{2}$} & a 1.02 & $\mathrm{dd}(11.0,3.8)$ & $8,9 b, 10$ & $7,8,10,14$ & $9 b, 8,7,14$ \\
\hline & & & b 2.21 & dd $(11.0,5.2)$ & $8,9 a, 10$ & $1,7,8,10,14$ & $9 a, 10$ \\
\hline 10 & 41.18 & $\mathrm{CH}$ & 2.02 & $\mathrm{~m}$ & $14,9 a, 9 b$ & $1,2,6,8,9,14$ & $9 b, 14$ \\
\hline 11 & 33.27 & $\mathrm{CH}$ & 1.45 & dsept $(9.3,6.7)$ & $7,12,13$ & $6,7,8,12,13$ & $6,12,13$ \\
\hline 12 & 21.81 & $\mathrm{CH}_{3}$ & 0.94 & $\mathrm{~d}(6.7)$ & 11 & $7,11,13$ & 11,13 \\
\hline 13 & 19.82 & $\mathrm{CH}_{3}$ & 0.87 & $\mathrm{~d}(6.7)$ & 11 & $7,11,12$ & $5,6,11,12$ \\
\hline 14 & 19.71 & $\mathrm{CH}_{3}$ & 1.07 & $\mathrm{~d}(7.4)$ & 10 & $1,9,10$ & $7,8,9 a, 10$ \\
\hline 15 & 22.65 & $\mathrm{CH}_{3}$ & 1.59 & br s & - & $3,4,5$ & $3 b, 5$ \\
\hline
\end{tabular}

${ }^{1} \mathrm{H},{ }^{13} \mathrm{C}-\mathrm{NMR}$ and DEPT spectra indicated the occurrence of a tri-substituted double bond $(\mathrm{C} 4,133.78 \mathrm{ppm}$ and $\mathrm{C} 5,122.89 \mathrm{ppm})$ and two carbons bearing the oxygen atom $(\mathrm{C}, 86.26 \mathrm{ppm}$ and $\mathrm{CH}$, $81.09 \mathrm{ppm}$ ), belonging to an oxide sub-structure. Taking into account the four unsaturation degrees and this double bond, compound 38 bears a tricyclic structure.

NMR spectra of 38 evidenced an isopropyl group (H11, 1.45 ppm, dsept: 9.3, 6.7 Hz; H12, 0.94 ppm, $\mathrm{d}: 6.7 \mathrm{~Hz})$ and H13, $0.87 \mathrm{ppm}, \mathrm{d}: 6.7 \mathrm{~Hz})$, a methyl group (H15, $1.59 \mathrm{ppm}$, broad s) linked to a sp ${ }^{2}$ quaternary carbon and another one (H14, $1.07 \mathrm{ppm}, \mathrm{d}: 7.4 \mathrm{~Hz})$ linked to a sp ${ }^{3}$ methine.

Starting from the methine linked to the oxygen atom $(\mathrm{CH}, 81.75 \mathrm{ppm}, 4.27 \mathrm{ppm}, \mathrm{d}, 5.2 \mathrm{~Hz})$ the HMBC correlations evidenced the oxa-bicyclo[2.2.1] heptane (oxa norbornane) substructure bearing the isopropyl group on $\mathrm{C} 7$ and the methyl group on C10. Correlation plots observed on the COSY spectrum between $\mathrm{H} 7$ and $\mathrm{H} 11$ on the one hand and between $\mathrm{H} 10$ and $\mathrm{H} 14$ on the other hand confirmed the position of both substituents on the oxa-norbornane framework. The last four carbons, including two $\mathrm{sp}^{2}$ carbons and two $\mathrm{sp}^{3}$ carbons, constituted the third cycle, obviously cyclohexenic. HMBC correlation plots allowed the positioning of the cyclohexene sub-structure vs. the oxa-norbornane moiety as well as the position of the methyl group on the double bond.

Therefore, the molecule under investigation possesses a bicyclo[4.4.0]decane skeleton with an oxide function between $\mathrm{C} 1$ and $\mathrm{C} 8$, drawing an oxa-norbornane sub-structure that bears a methyl on $\mathrm{C} 10$ and an isopropyl group on C7. The second cycle is a cyclohexene with a vinylic methyl on C4. Therefore, this molecule may be considered as a 1,8-oxido-cadin-4-ene.

Eight stereoisomers may be drawn, four of these display a cis stereochemistry of the bicyclo[4.4.0]decane ring junction, the last four display a trans stereochemistry of the ring junction. The relative configurations of the ring junction and those of carbons bearing the methyl and isopropyl groups were determined through NOESY correlations. Indeed, the observed correlation between $\mathrm{H} 7$ and H14 located the isopropyl group in the exo position vs. the oxa-norbornane sub-structure as well as the methyl 14 in the endo position. In parallel, the NOESY correlation between H6, H11 and H13 corroborated a cis junction of the bicyclo[4.4.0]decane framework.

The structure of compound $\mathbf{3 8}$ was elucidated as $(10 \beta \mathrm{H})-1 \beta, 8 \beta$-oxido-cadin-4-ene, a diastereoisomer of cis and trans-cadinene ethers, which displays a trans junction of the bicyclo[4.4.0]decane skeleton and a different stereochemistry to the isopropyl/methyl groups (Figure 1). 


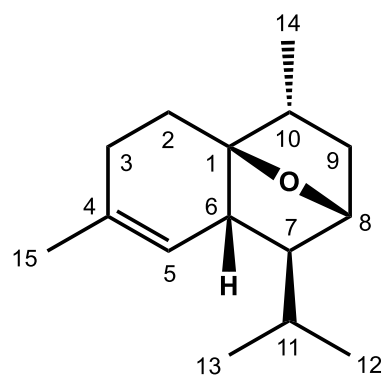

Figure 1. Structure of compound 38.

\subsubsection{Structure Elucidation of Compounds 52 and 53}

Sub-fraction F5.3.3 (26 mg) exhibited a single chromatographic peak- $(99.4 \%$ on GC apolar and polar columns). In contrast, the ${ }^{13} \mathrm{C}-\mathrm{NMR}$ spectrum of this sub-fraction displayed two series of 15 carbon signals easily distinguishable by their relative intensities (compounds $52+53$ ). The ratio calculated by the mean of protonated carbons' relative intensities was 7/3 (compounds 52/53).

The scanning of the chromatographic peak afforded super imposable mass spectra and the exact mass measured was $220.1823 \mathrm{~g} / \mathrm{mol}$, corresponding to $\mathrm{C}_{15} \mathrm{H}_{24} \mathrm{O}$ formula (calculated mass = $220.1822 \mathrm{~g} / \mathrm{mol}$ ). In addition, the two series of ${ }^{13} \mathrm{C}$ chemical shifts corresponding to these compounds were very similar. Indeed, each compound displayed six sp ${ }^{2}$ carbon signals, which consisted of two quaternary carbons, three methines and an ethylenic methylene (109.34 and 112.25 ppm, respectively; 52 and 53). The nine other signals belonged to $\mathrm{sp}^{3}$ carbons and each structure of compound was constituted of three methines, of which one carbon linked to an oxygen atom (69.57 and $73.13 \mathrm{ppm}$, respectively; 52 and 53), three methylenes and three methyl groups (Table 2) (Supplementary Materials, Figures S9-S17). Therefore, the ${ }^{13} \mathrm{C}-\mathrm{NMR}$ and DEPT spectra corroborated the $\mathrm{C}_{15} \mathrm{H}_{24} \mathrm{O}$ formula, which involved four unsaturation degrees. Each compound exhibited six $\mathrm{sp}^{2}$ carbons that belonged to three double bonds, which were obviously monocyclic; therefore, they may be considered more precisely as methylene cyclodecadienols and the various observations suggested the presence of two epimers.

Compounds 52 and 53, which co-eluted on apolar and polar columns, look uneasily separable by chromatographic techniques at our disposal. Therefore, the NMR extraction technique was used on the sub-fraction that contained only the two compounds $(99.4 \%$, ratio $7 / 3)$ for their structural elucidation $[17,18]$. This technique consisted of first assigning the ${ }^{1} \mathrm{H}$ and ${ }^{13} \mathrm{C}$ chemical shifts of each compound, taking into account the relative intensities of their signals and using the HSQC spectrum. Then, the specific correlations of each isomer were plotted on the other 2D-NMR spectra, i.e., COSY, NOESY, HMBC. Lastly, the determination of their respective structure was achieved by using the specific correlations belonging to each compound.

Concerning the major compound 52, NMR spectra evidenced an isopropyl group: H11 (1.69 ppm, m), H12 $(0.97 \mathrm{ppm}, \mathrm{d}: 6.7 \mathrm{~Hz})$ and $\mathrm{H} 13(0.87 \mathrm{ppm}, \mathrm{d}: 6.7 \mathrm{~Hz})$; as well as a methyl group linked to a sp2 quaternary carbon (H14, $1.71 \mathrm{ppm}$, broad s) and an exocyclic methylene (H15, 4.78 and 4.82 , br d: $2.3 \mathrm{~Hz}$ ). Therefore, the molecule contained the cyclodecadiene structure, substituted by a hydroxyl group. In addition, two deshielded methine signals $(C 8,69.57$ and $C 7,57.56 \mathrm{ppm})$ suggested a first carbon linked to the hydroxyl group and a carbon in $\alpha$ of the previous carbon, probably deshielded by the isopropyl group. This was confirmed by correlations observed on the HMBC spectrum, which evidenced that the isopropyl group was linked to C7. Multiplicity of vinylic proton signals (H5: 5.79 ppm, d, $16.1 \mathrm{~Hz}$; H6: 5.56 ppm, dd, 16.1, 9.8 Hz) demonstrated a $\mathrm{CH}=\mathrm{CH}$ double bond. According to the correlations observed on the $\mathrm{HMBC}$ spectrum, this double bond was located between $\mathrm{C} 7$ and the quaternary carbon $(\mathrm{C} 4,148.76 \mathrm{ppm})$ of the exocyclic $\mathrm{C}=\mathrm{CH}_{2}$. This was confirmed by correlation plots observed on the COSY, which also showed two proton groups formed by the sequences H1-H2-H3 and H5-H6-H7-H8-H9. The HMBC correlations of the hydrogens H1, H3 and H9 completed the structure of compound 52 as 4-methylene-germacra-1(10),5-dien-8-ol. 
Table 2. NMR data of compounds 52 and 53.

\begin{tabular}{|c|c|c|c|c|c|c|c|c|c|c|c|}
\hline \multicolumn{8}{|c|}{ Compound 52} & \multicolumn{4}{|c|}{ Compound 53} \\
\hline C & $\begin{array}{c}\delta^{13} \mathrm{C} \\
\text { (ppm) }\end{array}$ & DEPT & $\delta^{1} \mathbf{H}(\mathrm{ppm})$ & $\begin{array}{l}\text { Multiplicity } \\
(\mathrm{J}(\mathrm{Hz}))\end{array}$ & $\cos ^{1}{ }^{1} \mathbf{H}-{ }^{1} \mathbf{H}$ & HМBC $\mathrm{H} \rightarrow \mathrm{C}$ & NOESY ${ }^{1} \mathbf{H}_{-}{ }^{1} \mathbf{H}$ & $\begin{array}{c}\delta^{13} \mathrm{C} \\
(\mathrm{ppm})\end{array}$ & $\delta^{1} \mathbf{H}(\mathrm{ppm})$ & $\begin{array}{l}\text { Multiplicity } \\
(\mathrm{J}(\mathrm{Hz}))\end{array}$ & NOESY ${ }^{1} \mathbf{H}-{ }^{1} \mathbf{H}$ \\
\hline 1 & 132.27 & $\mathrm{CH}$ & 5.14 & br dd $(10.7,4.8)$ & $2 a, 2 b$ & $2,9,10,14$ & $2 b, 6,9 b$ & 130.27 & 5.63 & br dd $(10.6,5.0)$ & $2 b, 6,9 b$ \\
\hline \multirow{2}{*}{2} & \multirow{2}{*}{29.36} & \multirow{2}{*}{$\mathrm{CH}_{2}$} & a 1.99 & $\mathrm{~m}$ & $1,2 b, 3 a, 3 b$ & $1,3,4,5,10,15$ & $3 b, 14$ & \multirow{2}{*}{30.58} & a 2.16 & $\mathrm{~m}$ & $3 b, 14$ \\
\hline & & & b 2.46 & $\mathrm{~m}$ & $1,2 a, 3 a, 3 b$ & $1,3,4,5,10,15$ & $1,3 a, 15 b$ & & b 2.19 & $\mathrm{~m}$ & $1,3 a, 15 b$ \\
\hline \multirow{2}{*}{3} & \multirow{2}{*}{34.61} & \multirow{2}{*}{$\mathrm{CH}_{2}$} & a 2.13 & $\mathrm{~m}$ & $1,2 a, 2 b$ & $1,2,4,5,15$ & $2 b, 6,15 b$ & \multirow[b]{2}{*}{32.26} & a 2.22 & $\mathrm{~m}$ & $2 b, 6,15 b$ \\
\hline & & & b 2.48 & $\mathrm{~m}$ & $1,2 \mathrm{a}, 2 \mathrm{~b}$ & $1,2,4,5,15$ & $2 a, 5,8,14$ & & b 2.46 & $\mathrm{~m}$ & $2 a, 5,14$ \\
\hline 4 & 148.76 & $\mathrm{C}$ & - & - & - & - & - & 148.79 & - & - & - \\
\hline 5 & 137.36 & $\mathrm{CH}$ & 5.79 & $\mathrm{~d}(16.1)$ & 6 & $3,4,6,7,15$ & $3 b, 7,8,14$ & 127.64 & 6.06 & $\mathrm{~d}(16.3)$ & $3 b, 7,14$ \\
\hline 6 & 130.18 & $\mathrm{CH}$ & 5.56 & dd $(16.1,9.8)$ & 5,7 & $4,5,7,8,11$ & $1,2 b, 9 b, 11,13$ & 134.81 & 5.93 & $\mathrm{dd}(16.3,9.8)$ & $1,2 b, 9 b, 11,13$ \\
\hline 7 & 57.56 & $\mathrm{CH}$ & 1.93 & $\mathrm{dt}(9.8,2.5)$ & $6,8,11$ & $5,6,8,11,12,13$ & $5,8,12,13,14$ & 53.96 & 2.12 & $\mathrm{~m}$ & $5,12,13,14$ \\
\hline 8 & 69.57 & $\mathrm{CH}$ & 4.12 & $\mathrm{~m}$ & $7,9 a, 9 b$ & $6,7,9,10,11$ & $3 b, 5,7,14$ & 73.13 & 4.09 & $\mathrm{~m}$ & $9 a, 13$ \\
\hline \multirow[b]{2}{*}{9} & \multirow[b]{2}{*}{47.28} & \multirow{2}{*}{$\mathrm{CH}_{2}$} & a 2.39 & $\mathrm{dd}(14.0,2.3)$ & 8 & $1,7,8,10,14$ & $9 b, 14$ & \multirow{2}{*}{45.68} & a 2.02 & $\mathrm{dd}(14.2,4.0)$ & $8,9 b, 14$ \\
\hline & & & b 2.56 & $\mathrm{dd}(14.0,5.3)$ & 8 & $1,7,8,10,14$ & $1,6,9 a, 11$ & & b 2.70 & $\mathrm{dd}(14.2,6.8)$ & $1,6,9 a, 11$ \\
\hline 10 & 132.55 & $\mathrm{C}$ & - & - & - & - & - & 134.16 & - & - & - \\
\hline 11 & 28.47 & $\mathrm{CH}$ & 1.69 & $\mathrm{~m}$ & $7,12,13$ & $6,7,8,12,13$ & $6,9 b, 12,13$ & 27.44 & 1.97 & $\mathrm{~m}$ & $6,9 b, 12,13$ \\
\hline 12 & 20.52 & $\mathrm{CH}_{3}$ & 0.97 & $\mathrm{~d}(6.7)$ & 11 & $7,11,13$ & $7,11,13$ & 20.64 & 0.99 & $\mathrm{~d}(6.8)$ & $7,11,13$ \\
\hline 13 & 21.58 & $\mathrm{CH}_{3}$ & 0.87 & $\mathrm{~d}(6.7)$ & 11 & $7,11,12$ & $6,7,11,12$ & 21.86 & 0.94 & $\mathrm{~d}(6.8)$ & $6,8,11,12$ \\
\hline 14 & 19.34 & $\mathrm{CH}_{3}$ & 1.71 & br s & - & $1,2,8,9,10$ & $2 a, 3 b, 5,7,8,9 a$ & 19.53 & 1.44 & brs & $2 \mathrm{a}, 3 \mathrm{~b}, 5,7,9 \mathrm{a}$ \\
\hline \multirow{2}{*}{15} & \multirow{2}{*}{109.34} & \multirow{2}{*}{$\mathrm{CH}_{2}$} & a 4.78 & br d (2.3) & $15 b$ & $2,3,4,5$ & $3 b, 5,15 b$ & \multirow{2}{*}{112.25} & 4.71 & br d (2.2) & $3 b, 5,15 b$ \\
\hline & & & b 4.82 & br d (2.3) & $15 a$ & $2,3,4,5$ & $2 \mathrm{~b}, 3 \mathrm{a}, 15 \mathrm{a}$ & & 4.88 & br d (2.2) & $2 b, 3 a, 15 a$ \\
\hline
\end{tabular}


The (E) stereochemistry of the intracyclic double bonds was evidenced by the value of the coupling constant $(16.1 \mathrm{~Hz})$ for $\mathrm{C} 5=\mathrm{C} 6$ and by the occurrence of a correlation plot between $\mathrm{H} 1$ and $\mathrm{H} 9$ in the NOESY spectrum for $\mathrm{C} 1=\mathrm{C} 10$. The relative stereochemistry of the isopropyl and hydroxyl groups was determined through (i) the values of coupling constants of signals of geminated hydrogens; (ii) NOE spatial correlations observed between various protons. Indeed, $\mathrm{H} 6$ appears as a dd ( $\mathrm{J}_{\mathrm{H} 5-\mathrm{H} 6}=16.1 \mathrm{~Hz}$, and $\left.\mathrm{J}_{\mathrm{H} 6-\mathrm{H} 7}=9.8 \mathrm{~Hz}\right)$. In turn, the signal of $\mathrm{H7}$ is a dt $\left(\mathrm{J}_{\mathrm{H} 6-\mathrm{H} 7}=9.8 \mathrm{~Hz}, \mathrm{~J}_{\mathrm{H} 7-\mathrm{H} 11}=2.5 \mathrm{~Hz}\right.$ and $\mathrm{J}_{\mathrm{H} 7-\mathrm{H} 8}=2.5 \mathrm{~Hz}$ ). Assuming that the isopropyl group adopts an equatorial position, $\mathrm{H} 7 \mathrm{is}$ axial and the coupling constant value $\mathrm{J}_{\mathrm{H} 7-\mathrm{H} 8}=2.5 \mathrm{~Hz}$ locates $\mathrm{H} 8$ in equatorial position. Therefore, $\mathrm{H} 7$ and $\mathrm{H} 8$ display a cis stereochemistry as well as the isopropyl and hydroxyl groups and $\mathbf{5 2}$ is cis-germacrene D-8-ol. This point is corroborated by the observation in the NOESY spectrum of a correlation plot between $\mathrm{H} 7$ and $\mathrm{H} 8$, confirming that both protons are in the same side of the molecule. The structure of 52 is elucidated as 4-methylene-( $7 \alpha \mathrm{H})$-germacra- $1(10) E, 5 E$-dien- $8 \beta$-ol or germacrene-D- $8 \beta$-ol or cis-germacrene-D-8-ol (Figure 2).

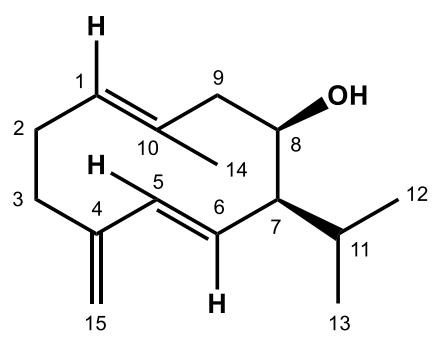

(7 $\alpha \mathrm{H})$-germacrene D-8 $\beta$-ol (52) = cis-germacrene D-8-ol<smiles>C=C1CC/C=C\C/C(C)=C/C1[C@H](O)C(C)C</smiles>

(7 $\alpha \mathrm{H})$-germacrene D-8 $\alpha$-ol (53) $=$ trans-germacrene D-8-ol

Figure 2. Structure of compounds 52 and 53.

Similarly, all correlations observed on HMBC and COSY spectra for the minor component 53 led to the same structure of germacrene D-8-ol. The E stereochemistry of the intracyclic double bonds is evidenced similarly to $\mathbf{5 2}$. Thus, compounds $\mathbf{5 2}$ and $\mathbf{5 3}$ are epimers. Unfortunately, signals of H7 and $\mathrm{H} 8$ appeared as multiplets and therefore they were not useful for stereochemical investigation. Moreover, the NOESY spectrum was not very informative. However, two points may be highlighted; (i) the occurrence of a correlation plot between H8 and H11 (absent in the spectrum of 52) and (ii) the lack of correlation plot between $\mathrm{H} 7$ and $\mathrm{H} 8$, which are located in a trans antiperiplanar conformation, this plot being observed in the spectrum of 52. Lastly, considering that the cyclodecadiene moiety adopts a chair-boat-chair conformation, the deshielding ( $3.5 \mathrm{ppm}$ ) of C8 in $\mathbf{5 3}$ vs. 52 is in agreement with the axial/equatorial stereochemistry of the hydroxyl group (compared with menthol/neo-menthol, for instance). Compound 53 is named 4-methylene- $(7 \alpha \mathrm{H})$-germacra- $1(10), 5$-dien- $8 \alpha$-ol or $(7 \alpha \mathrm{H})$ germacrene $\mathrm{d}-8 \alpha$-ol or trans-germacrene $\mathrm{D}-8-\mathrm{ol}$.

\subsubsection{Structure Elucidation of Compound 56}

Sub-fraction F5.3.1 (19 mg) contained compound 56 (98.3\%), with RIs apol/pol = 1676/2276, suggesting an oxygenated sesquiterpene. The electron ionization (EI)-mass spectrum of compound 56 exhibited an $m / z=220$ molecular ion peak $\left(\mathrm{M}^{\bullet+}\right)$ and an $\mathrm{M}^{\bullet+}-18$ peak $(m / z=202)$, characteristic of a sesquiterpene alcohol. However, no structure proposal emerged from GC-MS analysis with an acceptable fit (commercial MS libraries and home-made MS library). Therefore, structural elucidation was undertaken.

The measured exact mass was $220.1823 \mathrm{~g} / \mathrm{mol}$, corresponding to $\mathrm{C}_{15} \mathrm{H}_{24} \mathrm{O}$ formula (calculated mass $=220.1822 \mathrm{~g} / \mathrm{mol}$ ). The ${ }^{1} \mathrm{H}-\mathrm{NMR},{ }^{13} \mathrm{C}-\mathrm{NMR}$ and DEPT spectra were in agreement with this formula, which involved four unsaturation degrees. These spectra also confirmed the presence of an alcohol function (C8, 65.54 ppm) (Table 3) (Supplementary Materials, Figures S18-S26). Four $\mathrm{sp}^{2}$ carbon signals including three quaternary carbons, involved in two $\mathrm{C}=\mathrm{C}$ double bonds, 
were observed. Taking into account the four unsaturation degrees, compound 57 obviously bears a bicyclic structure. The ${ }^{1} \mathrm{H}-\mathrm{NMR}$ spectrum evidenced an isopropyl group: $\mathrm{H} 11$ (1.45 ppm, dsept: 9.3, $6.7 \mathrm{~Hz}), \mathrm{H} 12(0.94 \mathrm{ppm}, \mathrm{d}: 6.7 \mathrm{~Hz})$ and $\mathrm{H} 13(0.87 \mathrm{ppm}, \mathrm{d}: 6.7 \mathrm{~Hz})$; confirmed by the COSY spectrum and two methyl groups linked to $\mathrm{sp}^{2}$ quaternary carbons (H14, $1.67 \mathrm{ppm}$, broad s; H15, $1.69 \mathrm{ppm}$, broad s). COSY correlations also evidenced two other hydrogen groups formed by the sequences $\mathrm{H} 2-\mathrm{H} 3$ and $\mathrm{H} 5-\mathrm{H} 6-\mathrm{H} 7-\mathrm{H} 8-\mathrm{H} 9$ and they indicated that the isopropyl group was linked to C7.

Table 3. NMR data of compound 56.

\begin{tabular}{|c|c|c|c|c|c|c|c|}
\hline $\mathrm{C}$ & $\begin{array}{c}\delta^{13} \mathrm{C} \\
\text { (ppm) }\end{array}$ & DEPT & $\begin{array}{c}\delta^{1} \mathbf{H} \\
(\mathrm{ppm})\end{array}$ & $\begin{array}{l}\text { Multiplicity } \\
(\mathrm{J}(\mathrm{Hz}))\end{array}$ & $\begin{array}{l}\text { COSY } \\
{ }^{1} \mathbf{H}-{ }^{1} \mathbf{H}\end{array}$ & HMBC $\mathbf{H} \rightarrow \mathrm{C}$ & $\begin{array}{l}\text { NOESY } \\
{ }^{1}{ }^{1}-{ }^{1} \mathbf{H}^{a}\end{array}$ \\
\hline 1 & 130.31 & $\mathrm{C}$ & - & - & - & - & - \\
\hline \multirow{2}{*}{2} & \multirow{2}{*}{26.70} & \multirow{2}{*}{$\mathrm{CH}_{2}$} & a 1.99 & $\mathrm{~m}$ & $2 b, 3$ & $1,3,4,6,10$ & $2 b, 3$ \\
\hline & & & b 2.74 & $\begin{array}{c}\text { ddd }(12.2,3.6 \\
3.1)\end{array}$ & $2 a, 3$ & $1,3,4,6,10$ & $2 a, 3,14$ \\
\hline 3 & 32.05 & $\mathrm{CH}_{2}$ & a 2.04 & $\mathrm{~m}$ & $2 a, 2 b$ & $1,2,4,5,15$ & $2 a, 2 b, 15$ \\
\hline 4 & 134.83 & $\mathrm{C}$ & - & - & - & - & - \\
\hline 5 & 123.99 & $\mathrm{CH}$ & 5.45 & m (1.5) & 6 & $1,4,6,7,15$ & 6,15 \\
\hline 6 & 34.93 & $\mathrm{CH}$ & 2.86 & br d (11.0) & 5,7 & $1,2,4,5,7,10$ & $5,9 b, 11,13$ \\
\hline 7 & 48.03 & $\mathrm{CH}$ & 1.15 & $\begin{array}{c}\text { br dd (11.0, } \\
4.3)\end{array}$ & $6,8,11$ & $5,6,8,11,12,13$ & $8,9 a, 14$ \\
\hline 8 & 65.54 & $\mathrm{CH}$ & 4.17 & $\mathrm{~m}$ & $7,9 a, 9 b$ & $6,7,9,10,11$ & $7,9 a, 14$ \\
\hline 9 & 41.81 & $\mathrm{CH}_{2}$ & $\begin{array}{l}\text { a } 2.04 \\
\text { b } 2.30\end{array}$ & $\frac{\mathrm{m}}{\mathrm{dd}(17.3,4.1)}$ & $\begin{array}{l}8,9 \mathrm{~b} \\
8,9 \mathrm{a}\end{array}$ & $\begin{array}{l}1,7,8,10,14 \\
1,7,8,10,14\end{array}$ & $\begin{array}{c}9 b, 8,7,14 \\
9 a, 6,11,12\end{array}$ \\
\hline 10 & 119.79 & $\mathrm{C}$ & - & - & - & - & - \\
\hline 11 & 27.14 & $\mathrm{CH}$ & 2.10 & dsept $(7.0,4.1)$ & $7,12,13$ & $6,7,8,12,13$ & $6,12,13$ \\
\hline 12 & 18.50 & $\mathrm{CH}_{3}$ & 1.04 & $\mathrm{~d}(7.0)$ & 11 & $7,11,13$ & $9 b, 11,13$ \\
\hline 13 & 21.79 & $\mathrm{CH}_{3}$ & 1.05 & $\mathrm{~d}(7.0)$ & 11 & $7,11,12$ & $6,11,12$ \\
\hline 14 & 18.74 & $\mathrm{CH}_{3}$ & 1.67 & brs & - & $1,9,10$ & $2 b, 8,7$ \\
\hline 15 & 23.62 & $\mathrm{CH}_{3}$ & 1.69 & brs & - & $3,4,5$ & 3,5 \\
\hline
\end{tabular}

${ }^{a}$ Most relevant NOE correlations.

Correlation plots in the HMBC spectrum allowed the construction of the bicyclic skeleton. For instance, proton $\mathrm{H} 8$ geminated to the hydroxyl function correlates with $\mathrm{C} 6, \mathrm{C} 7, \mathrm{C} 9$ and the ethylenic quaternary carbon $\mathrm{C} 10$. Proton $\mathrm{H} 6$, located at the ring junction, correlates with $\mathrm{C} 1, \mathrm{C} 2$ and $\mathrm{C} 10$ on the one hand and with C4, C5 and C7 on the other hand. Otherwise, protons H14 and H15 correlated with $\mathrm{sp}^{2}$ quaternary carbons $\mathrm{C} 10$ and $\mathrm{C} 4$. Thus, the $\mathrm{C} 14$ and $\mathrm{C} 15$ methyl groups were linked to $\mathrm{C} 10$ and $\mathrm{C} 4$, respectively. It is possible to determine the structure of compound 56 as cadina-1(10),4-dien-8-ol.

The relative stereochemistry of substituents of compound 56 was established through NOESY spatial correlations. Protons H6, H11, H12 and H13 correlated together indicating a cis stereochemistry of $\mathrm{H} 6$ and the isopropyl group. Similarly, $\mathrm{H} 7$ correlated with $\mathrm{H} 8$ leading to the cis stereochemistry of the isopropyl group and the hydroxyl function. Coupling constants of $\mathrm{H6}(11.0 \mathrm{~Hz})$ and H7 $(11.0$ and $4.3 \mathrm{~Hz})$ are in agreement with NOESY correlations. Therefore, compound 56 is cadina-1(10), 4-dien-8 $\beta$-ol (Figure 3).

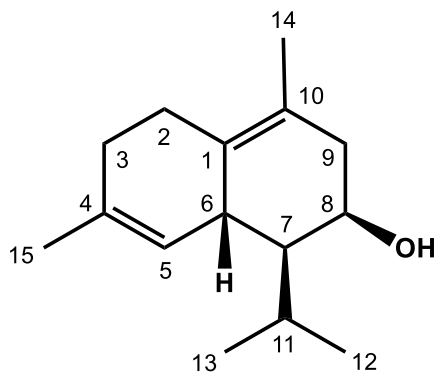

Figure 3. Structure of compound 56. 
This compound is an epimer of cadina-1(10),4-dien- $8 \alpha$-ol isolated by Weyerstahl et al. [19] from the essential oil of Iranian Pulicaria gnaphalodes (Vent.) Boiss. Differences in chemical shifts of both isomers agree with the axial/equatorial stereochemistry of the hydroxyl group, particularly the shielding of C6 due to the $\gamma$ steric effect of the hydroxyl group.

However, bibliographic investigations carried out in the literature have indicated that the occurrence of compound $\mathbf{5 6}$ has been already mentioned in two studies:

In the first one, a compound has been identified in the aerial parts of Ferula flabelliloba on the basis of its mass spectrum as being cadina-1(10),4-dien-8 $\beta$-ol [20]. However, the structure represented by the authors, drawing a cis stereochemistry of H6 (hydrogen of the ring junction) and the isopropyl group and a trans stereochemistry of the isopropyl and hydroxyl groups, was rather that of the $8 \alpha$ isomer (Figure 3). Moreover, it could be pointed out that the measured retention index (RI) (CP Sil $5 \mathrm{CB})=1678$ [20] fitted with RI (CP Sil 5 CB) $=1680$ measured for the $8 \alpha$ isomer [21] and RI (DB1) measured for the $8 \beta$ isomer (1676; this work).

In the second study, cadina-1(10),4-dien-8 $\beta$-ol was identified by the retention index ( $R I=1663$, CP Sil 5 CB) and mass spectrum in different organs of Erigeron annuus [22].

However, to the best of our knowledge, NMR data of cadina-1(10),4-dien-8 $\beta$-ol were not found in the literature. Therefore, the present study is the first available structural elucidation of that compound.

\subsection{Chemical Composition of Leaf Essential Oil from I. dewevrei}

The chemical composition of two essential oil samples $(\mathrm{S} 1, \mathrm{~S} 2)$ from wild I. dewevrei was determined by a combination of repetitive column chromatography (CC), GC(RI), GC-MS and ${ }^{13}$ C-NMR. In total, fifty-seven components accounting for 95.5 and $97.1 \%$ of the composition of the whole oil sample were identified. Compounds 38, 52 and 53 are reported for the first time, whereas NMR data of 56 are described for the first time. The composition of the two leaf oil samples (S1 and S2) was largely dominated by oxygenated sesquiterpenes (44.1 and $44.9 \%$, respectively) and hydrocarbon sesquiterpenes (41.2 and 40.2\%, respectively), the sesquiterpene fraction accounting for 85.3 and $85.1 \%$, respectively (Table 4 ).

Table 4. Chemical composition of leaf essential oil from Isolona dewevrei.

\begin{tabular}{|c|c|c|c|c|c|c|c|}
\hline $\mathbf{N}^{\circ}$ & Compounds & RIa & RIp & RFF & $\begin{array}{c}\text { S1 } \\
(\%)\end{array}$ & $\begin{array}{c}\text { S2 } \\
(\%)\end{array}$ & Identification \\
\hline 1 & $\alpha$-Thujene & 923 & 1016 & 0.765 & $\operatorname{tr}$ & 0.1 & RI, MS \\
\hline 2 & $\alpha$-Pinene & 931 & 1013 & 0.765 & 0.1 & 0.1 & RI, MS \\
\hline 3 & Sabinene & 965 & 1120 & 0.765 & 0.1 & 0.4 & RI, MS, ${ }^{13} \mathrm{C}-\mathrm{NMR}$ \\
\hline 4 & $\beta$-Pinene & 970 & 1109 & 0.765 & 0.1 & 0.2 & RI, MS, ${ }^{13} C-N M R$ \\
\hline 5 & Myrcene & 981 & 1158 & 0.765 & 0.3 & 0.3 & RI, MS, ${ }^{13} C-N M R$ \\
\hline 6 & $\alpha$-Terpinene & 1009 & 1178 & 0.765 & 0.1 & 0.1 & RI, MS \\
\hline 7 & p-Cymene & 1012 & 1268 & 0.698 & $\operatorname{tr}$ & 0.1 & RI, MS, ${ }^{13} \mathrm{C}-\mathrm{NMR}$ \\
\hline$\beta$ & Limonene & 1021 & 1199 & 0.765 & 1.1 & 1.1 & RI, MS, ${ }^{13} \mathrm{C}-\mathrm{NMR}$ \\
\hline 9 & (Z)- $\beta$-Ocimene & 1025 & 1230 & 0.765 & 3.4 & 4.5 & RI, MS, ${ }^{13} \mathrm{C}-\mathrm{NMR}$ \\
\hline 10 & (E)- $\beta$-Ocimene & 1036 & 1247 & 0.765 & 4.5 & 4.2 & RI, MS, ${ }^{13} \mathrm{C}-\mathrm{NMR}$ \\
\hline 11 & $\gamma$-Terpinene & 1048 & 1242 & 0.765 & 0.2 & 0.2 & RI, MS, ${ }^{13} \mathrm{C}-N M R$ \\
\hline 12 & Linalool & 1083 & 1543 & 0.869 & $\operatorname{tr}$ & 0.1 & RI, MS \\
\hline 13 & allo-Ocimene & 1117 & 1370 & 0.765 & 0.1 & 0.2 & RI, MS, ${ }^{13} \mathrm{C}-\mathrm{NMR}$ \\
\hline 14 & Terpinen-4-ol & 1161 & 1597 & 0.869 & - & 0.1 & RI, MS \\
\hline 15 & Geraniol & 1233 & 1843 & 0.869 & 0.1 & 0.2 & RI, MS, ${ }^{13} C-N M R$ \\
\hline 16 & Geranial & 1244 & 1740 & 0.887 & 0.1 & 0.1 & RI, MS, ${ }^{13}$ C-NMR \\
\hline 17 & $\delta$-Elemene & 1334 & 1464 & 0.751 & $\operatorname{tr}$ & 0.5 & RI, MS, ${ }^{13} \mathrm{C}-\mathrm{NMR}$ \\
\hline 18 & $\alpha$-Cubebene & 1347 & 1452 & 0.751 & 0.1 & 0.1 & RI, MS \\
\hline 19 & $\alpha$-Copaene & 1374 & 1485 & 0.751 & 0.9 & 0.7 & RI, MS, ${ }^{13} \mathrm{C}-\mathrm{NMR}$ \\
\hline
\end{tabular}


Table 4. Cont.

\begin{tabular}{|c|c|c|c|c|c|c|c|}
\hline $\mathbf{N}^{\circ}$ & Compounds & RIa & RIp & RFF & $\begin{array}{l}\text { S1 } \\
(\%)\end{array}$ & $\begin{array}{l}\mathrm{S} 2 \\
(\%)\end{array}$ & Identification \\
\hline 20 & $\beta$-Elemene & 1385 & 1583 & 0.751 & 1.6 & 1.7 & RI, MS, ${ }^{13} \mathrm{C}-\mathrm{NMR}$ \\
\hline 21 & (E)- $\beta$-Caryophyllene * & 1416 & 1589 & 0.751 & 5.3 & 5.7 & RI, MS, ${ }^{13} \mathrm{C}-\mathrm{NMR}$ \\
\hline 22 & $\alpha$-Santalene * & 1416 & 1565 & 0.751 & 0.1 & 0.3 & RI, MS, ${ }^{13} C-N M R$ \\
\hline 23 & $\gamma$-Elemene \# & 1426 & 1630 & 0.751 & $\operatorname{tr}$ & 0.5 & RI, MS, ${ }^{13} \mathrm{C}-\mathrm{NMR}$ \\
\hline 24 & $(E)$ - $\beta$-Farnesene & 1446 & 1660 & 0.751 & 0.1 & 0.1 & RI, MS \\
\hline 25 & $\alpha$-Humulene & 1448 & 1662 & 0.751 & 1.7 & 1.3 & RI, MS, ${ }^{13} \mathrm{C}-\mathrm{NMR}$ \\
\hline 26 & $\alpha$-Curcumene & 1469 & 1766 & 0.707 & $\operatorname{tr}$ & $\operatorname{tr}$ & RI, MS, ${ }^{13} \mathrm{C}-\mathrm{NMR}$ \\
\hline 27 & $\gamma$-Muurolene & 1471 & 1683 & 0.751 & 0.3 & 0.3 & RI, MS, ${ }^{13} C-N M R$ \\
\hline 28 & Germacrene D & 1474 & 1700 & 0.751 & 23.6 & 20.5 & RI, MS, ${ }^{13}$ C-NMR \\
\hline 29 & trans- $\beta$-Bergamotene & 1478 & 1676 & 0.751 & $\operatorname{tr}$ & 0.2 & RI, MS, ${ }^{13} \mathrm{C}-\mathrm{NMR}$ \\
\hline 30 & $\beta$-Selinene & 1484 & 1710 & 0.751 & 0.1 & $\operatorname{tr}$ & RI, MS \\
\hline 31 & Bicyclogermacrene & 1489 & 1721 & 0.751 & 1.8 & 1.6 & RI, MS, ${ }^{13} \mathrm{C}-\mathrm{NMR}$ \\
\hline 32 & $\alpha$-Selinene & 1493 & 1717 & 0.751 & 0.2 & 0.2 & RI, MS, ${ }^{13} \mathrm{C}-\mathrm{NMR}$ \\
\hline 33 & $\beta$-Bisabolene & 1500 & 1719 & 0.751 & 0.2 & 0.2 & RI, MS, ${ }^{13} \mathrm{C}-\mathrm{NMR}$ \\
\hline 34 & $\delta$-Cadinene & 1512 & 1753 & 0.751 & 2.5 & 2.4 & RI, MS, ${ }^{13} \mathrm{C}-\mathrm{NMR}$ \\
\hline 35 & cis-Lanceol & 1517 & 2087 & 0.819 & 0.9 & 0.7 & RI, MS, ${ }^{13} \mathrm{C}-\mathrm{NMR}$ \\
\hline 36 & (Z)- $\gamma$-Bisabolene & 1521 & 1721 & 0.751 & 1.4 & 1.5 & RI, MS, ${ }^{13} \mathrm{C}-\mathrm{NMR}$ \\
\hline 37 & trans-Sesquisabinene hydrate & 1530 & 1984 & 0.819 & $\operatorname{tr}$ & 0.1 & RI, MS \\
\hline 38 & $(10 \beta H)-1 \beta, 8 \beta$-Oxido-cadin-4-ene & 1534 & 1853 & 0.830 & 7.3 & 8.7 & $\begin{array}{l}\text { QTOF-MS, 1D, } \\
\text { 2D-NMR }\end{array}$ \\
\hline 39 & $\beta$-Elemol & 1536 & 2077 & 0.819 & $\operatorname{tr}$ & 0.2 & RI, MS, ${ }^{13} C-N M R$ \\
\hline 40 & (E)-Nerolidol & 1547 & 2034 & 0.819 & 0.5 & 1.1 & RI, MS, ${ }^{13} \mathrm{C}-\mathrm{NMR}$ \\
\hline 41 & Germacrene B \# & 1549 & 1818 & 0.751 & 1.3 & 2.4 & RI, MS, ${ }^{13} \mathrm{C}-\mathrm{NMR}$ \\
\hline 42 & cis-Sesquisabinene hydrate & 1562 & 2079 & 0.819 & 0.3 & 0.2 & RI, MS, ${ }^{13} \mathrm{C}-\mathrm{NMR}$ \\
\hline 43 & Caryophyllene oxide & 1567 & 1973 & 0.830 & 0.1 & 0.2 & RI, MS, ${ }^{13} \mathrm{C}-\mathrm{NMR}$ \\
\hline 44 & Germacrene D-8-one & 1584 & 2066 & 0.841 & 8.9 & 8.7 & RI, MS, ${ }^{13} \mathrm{C}-\mathrm{NMR}$ \\
\hline 45 & Humulene oxide II & 1597 & 2042 & 0.830 & 0.4 & 0.2 & RI, MS, ${ }^{13} \mathrm{C}-\mathrm{NMR}$ \\
\hline 46 & Alismol & 1609 & 2245 & 0.830 & 0.1 & 0.3 & RI, MS, ${ }^{13} \mathrm{C}-N M R$ \\
\hline 47 & $\gamma$-Eudesmol & 1620 & 2172 & 0.819 & 1.2 & 1.2 & RI, MS, ${ }^{13} \mathrm{C}-\mathrm{NMR}$ \\
\hline 48 & $\delta$-Cadinol & 1626 & 2174 & 0.819 & 0.1 & 0.2 & RI, MS, ${ }^{13} \mathrm{C}-N M R$ \\
\hline 49 & Muurola-4,10(14)-dien-8 $\beta$-ol & 1629 & 2186 & 0.830 & 3.2 & 2.9 & RI, MS, ${ }^{13} \mathrm{C}-\mathrm{NMR}$ \\
\hline 50 & $\alpha$-Cadinol & 1634 & 2231 & 0.819 & 0.6 & 0.6 & RI, MS, ${ }^{13} \mathrm{C}-\mathrm{NMR}$ \\
\hline 51 & $\beta$-Bisabolol & 1653 & 2144 & 0.819 & 0.2 & 0.2 & RI, MS, ${ }^{13} \mathrm{C}-\mathrm{NMR}$ \\
\hline 52 & $(7 \alpha \mathrm{H})$-Germacrene D- $8 \beta$-ol * & 1657 & 2355 & 0.819 & 7.8 & 7.4 & $\begin{array}{l}\text { QTOF-MS, 1D, } \\
\text { 2D-NMR }\end{array}$ \\
\hline 53 & $(7 \alpha \mathrm{H})$-Germacrene $\mathrm{D}-\alpha \beta$-ol * & 1657 & 2355 & 0.819 & 2.6 & 2.5 & $\begin{array}{l}\text { QTOF-MS, 1D, } \\
\text { 2D-NMR }\end{array}$ \\
\hline 54 & $\alpha$-Bisabolol & 1664 & 2208 & 0.819 & 1.4 & 1.5 & RI, MS, ${ }^{13} \mathrm{C}-\mathrm{NMR}$ \\
\hline 55 & epi- $\alpha$-Bisabolol & 1667 & 2214 & 0.819 & 0.1 & $\operatorname{tr}$ & RI, MS, ${ }^{13} \mathrm{C}-\mathrm{NMR}$ \\
\hline 56 & Cadina-1(10),4-dien-8 $\beta$-ol & 1676 & 2276 & 0.819 & 7.6 & 7.2 & $\begin{array}{l}\text { QTOF-MS, 1D, } \\
\text { 2D-NMR }\end{array}$ \\
\hline 57 & Cadina-4,10(14)-dien-8 $\beta$-ol & 1678 & 2280 & 0.830 & 0.8 & 0.8 & RI, MS, ${ }^{13}$ C-NMR \\
\hline & Hydrocarbon monoterpenes & & & & 10.0 & 11.5 & \\
\hline & Oxygenated monoterpenes & & & & 0.2 & 0.5 & \\
\hline & Hydrocarbon sesquiterpenes & & & & 41.2 & 40.2 & \\
\hline & Oxygenated sesquiterpenes & & & & 44.1 & 44.9 & \\
\hline & Total & & & & 95.5 & 97.1 & \\
\hline
\end{tabular}

Order of elution and percentages are given on an apolar column (BP-1), except components with an asterisk $\left({ }^{*}\right)$, where percentages are taken on a polar column (BP-20). (\#) Thermolabile compound, percentage evaluated by a combination of GC-FID and ${ }^{13}$ C-NMR data [7]. RIa, RIp: retention indices measured on apolar and polar capillary column, respectively. RRF: relative response factors calculated using methyl octanoate as internal standard. The relative proportions of constituent are expressed in g/100 g. tr: traces level $(<0.05 \%) .{ }^{13} C-N M R$ : compounds identified by NMR in the essential oil samples and obvious in at least one fraction of chromatography; ${ }^{13} \mathrm{C}-\mathrm{NMR}$ (italic): compounds identified by NMR in fractions of chromatography. 
Essential oil samples S1 and S2 displayed close chemical compositions, dominated by germacrene $\mathrm{D}$ (23.6 and 20.5\%, respectively), followed by germacrene $\mathrm{D}-8$-one ( 8.9 and $8.7 \%)$, $(10 \beta \mathrm{H})-1 \beta, 8 \beta$-oxido-cadin-4-ene (38) (7.3 and 8.7\%), $(7 \alpha \mathrm{H})$-germacrene $\mathrm{D}-8 \beta$-ol (52) $(7.8$ and $7.4 \%)$ and cadina-1(10),4-dien-8 $\beta$-ol (56) (7.6 and 7.2\%). Other compounds were also present in both samples at appreciable contents: (E)- $\beta$-caryophyllene (5.3 and 5.7\%), (E)- $\beta$-ocimene (4.5 and $4.2 \%)$ and (Z)- $\beta$-ocimene ( 3.4 and $4.5 \%$ ).

Investigations carried out on I. dewevrei leaf essential oil, using a combination of chromatographic (CC, GC(RI)) and spectroscopic techniques (GC-MS, $\left.{ }^{13} \mathrm{C}-\mathrm{NMR}\right)$, led to the identification of fifty-seven constituents accounting for 95.51 and $97.1 \%$ of the whole oil samples' compositions. The two samples were characterized by a similar chemical composition dominated by germacrene $\mathrm{D}(23.6$ and $20.5 \%$, respectively), followed by germacrene $\mathrm{D}-8$-one $(8.9$ and $8.7 \%),(10 \beta \mathrm{H})-1 \beta, 8 \beta$-epoxy-cadina-4-ene (38) $(7.3$ and $8.7 \%),(7 \alpha \mathrm{H})$-germacrene $\mathrm{D}-8 \beta$-ol (52) (7.8 and 7.4\%) and cadina-1(10),4-dien-8 $\beta$-ol (56) $(7.6$ and $7.2 \%)$. Compounds 38,52 as well as $(7 \alpha \mathrm{H})$-germacrene D- $8 \alpha$-ol 53 are new natural sesquiterpenes, isolated from sample S2 and fully characterized by QTOF-MS, 1D and 2D-NMR. In addition, cadina-1(10),4-dien-8 $\beta$-ol (56) was also isolated from this oil sample and its NMR data are reported for the first time.

Leaves from I. deweorei produced a sesquiterpene-rich essential oil with an original chemical composition, displaying various compounds that are reported for the first time. The previously reported chemical composition of leaf oil from this species was dominated by germacrene $\mathrm{B}$, $(5 \alpha \mathrm{H}, 10 \beta \mathrm{Me})$-6,12-oxido-elema-1,3,6,11(12)-tetraene, germacrene $\mathrm{D},(\mathrm{Z})$ - $\beta$-ocimene, $\gamma$-elemene and (E)- $\beta$-caryophyllene [14]. Thus, qualitative and quantitative differences appeared between the compositions of the previous and the present study. Hence, the chemical variability of the leaf essential oil of $I$. dewevrei should be evaluated by investigating a larger number of oil samples.

\section{Materials and Methods}

\subsection{Plant Material}

The fresh leaves samples (2210 and $2412 \mathrm{~g}$, respectively) were collected on individual I. dewevrei trees, which were growing in different ecological conditions, in the Bossématié forest (region of Abengourou, Eastern Côte d'Ivoire, geographical coordinates: $6^{\circ} 26^{\prime} 57.9^{\prime \prime} \mathrm{N}$ and $3^{\circ} 28^{\prime} 47.5^{\prime \prime} \mathrm{O}$ ) in April 2016. Plant material was authenticated by botanists from Centre Suisse de Recherches Scientifiques (CSRS) and Centre National de Floristique (CNF) Abidjan, Côte d'Ivoire. A voucher specimen was deposited at the herbarium of CNF, Abidjan, with the reference LAA 12874.

\subsection{Essential Oil Isolation and Fractionation}

The essential oil samples (S1 and S2) were obtained by hydrodistillation of fresh leaves for $3 \mathrm{~h}$ using a Clevenger-type apparatus. Yields were calculated from fresh material $(w / w)$. The oil sample S2 $(2.9 \mathrm{~g})$ was repeatedly fractionated by column chromatography (CC) as shown on Scheme 1, using a gradient of solvents, $n$-pentane: diethyl ether of increasing polarity. Silica gel (200-500 $\mu \mathrm{m}, 90 \mathrm{~g})$ was used to afford the first eight fractions. Fractions F4 and F5 were again fractionated with silica gel $(60-200 \mu \mathrm{m}, 20 \mathrm{~g}$ each). Sub-fractions F4.2, F4.3 and F5.2 were then fractionated with silica gel (35-70 $\mu \mathrm{m}, 10,6$ and $10 \mathrm{~g}$, respectively). Lastly, sub-fraction F5.3 was submitted to a Sephadex LH-20 column $(3.0 \mathrm{~g})$ using chloroform. Compound 38 (98.7\%) was the main constituent of sub-fraction F4.3.1. Sub-fraction F5.3.1 contained compound 56 (98.3\%) and sub-fraction F5.3.3 contained compounds 52 and 53 , both accounting for $99.4 \%$ (ratio $7 / 3$ ). 


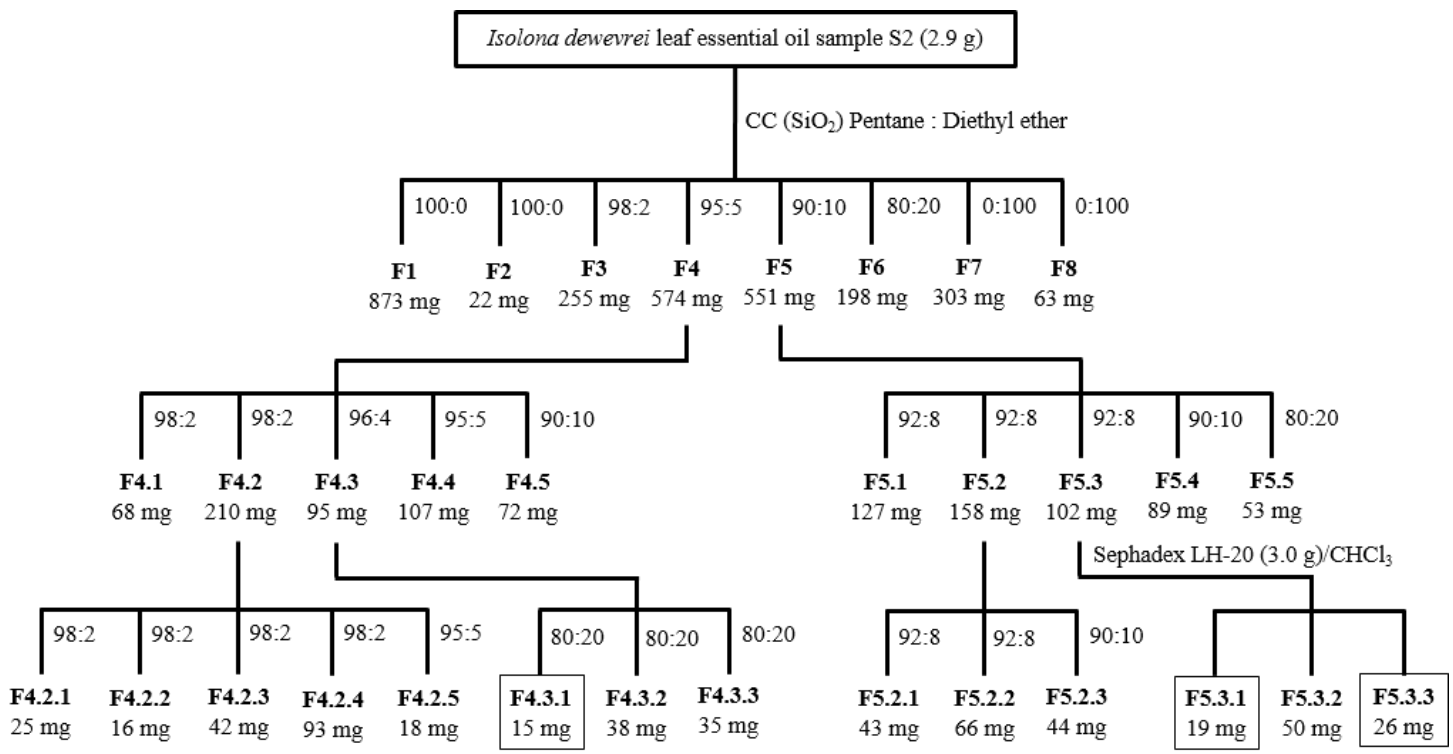

Scheme 1. Fractionation process of leaf essential oil sample S2.

\subsection{Gas Chromatography}

Analyses were performed on a Clarus 500 PerkinElmer Chromatograph (PerkinElmer, Courtaboeuf, France), equipped with flame ionization detector (FID) and two fused-silica capillary columns ( $50 \mathrm{~m} \times 0.22 \mathrm{~mm}$, film thickness $0.25 \mu \mathrm{m}$ ), BP-1 (polydimethylsiloxane) and BP-20 (polyethylene glycol). The oven temperature was programmed from $60^{\circ} \mathrm{C}$ to $220^{\circ} \mathrm{C}$ at $2{ }^{\circ} \mathrm{C} / \mathrm{min}$ and then held isothermal at $220{ }^{\circ} \mathrm{C}$ for $20 \mathrm{~min}$; injector temperature: $250{ }^{\circ} \mathrm{C}$; detector temperature: $250{ }^{\circ} \mathrm{C}$; carrier gas: helium ( $0.8 \mathrm{~mL} / \mathrm{min})$; split: $1 / 60$; injected volume: $0.5 \mu \mathrm{L}$. Retention indices (RI) were determined relative to the retention times of a series of $n$-alkanes (C8-C29) with linear interpolation ("Target Compounds » software from PerkinElmer). The relative response factor (RFF) of each compound was calculated according to the IOFI recommended practice for the use of predicted relative response factors for the rapid quantification of volatile flavoring compounds by GC(FID) [23]. Methyl octanoate was used as an internal reference and the relative proportion of each constituent (expressed in $\mathrm{g} / 100 \mathrm{~g}$ ) was calculated using the weight of essential oil and reference, peak area and relative response factors (RRF).

\subsection{Gas Chromatography-Mass Spectrometry in Electron Impact Mode}

The essential oil samples and all fractions of chromatography were analyzed with a PerkinElmer TurboMass detector (quadrupole), directly coupled with a PerkinElmer Autosystem XL (PerkinElmer, Courtaboeuf, France), equipped with a Rtx-1 (polydimethylsiloxane) fused-silica capillary column $(60 \mathrm{~m} \times 0.22 \mathrm{~mm}$ i.d., film thickness $0.25 \mu \mathrm{m})$. The oven temperature was programmed from 60 to $230^{\circ} \mathrm{C}$ at $2^{\circ} / \mathrm{min}$ and then held isothermal for $45 \mathrm{~min}$; injector temperature, $250^{\circ} \mathrm{C}$; ion-source temperature, $250{ }^{\circ} \mathrm{C}$; carrier gas, $\mathrm{He}(1 \mathrm{~mL} / \mathrm{min})$; split ratio, 1:80; injection volume, $0.2 \mu \mathrm{L}$; ionization energy, $70 \mathrm{eV}$. The electron ionization (EI) mass spectra were acquired over the mass range 35-350 Da.

\subsection{Gas Chromatography-High Resolution Mass Spectrometry}

High-resolution EI-mass spectra were recorded using an Agilent 7200 GC-QTOF system (Agilent, Santa Clara, CA, USA) equipped with an Agilent J\&W, VF-waxMS capillary column (30 $\mathrm{m} \times 0.25 \mathrm{~mm} ; 0.25 \mu \mathrm{m}$ film thickness). The mass spectrometer was operating at $70 \mathrm{eV}$ with an acquisition rate of $2 \mathrm{GHz}$ over a 35-450 $\mathrm{m} / \mathrm{z}$ range, affording a resolution of $\sim 8000$. Injection volume $1 \mu \mathrm{L}$; split ratio 1:20; inlet temperature $250^{\circ} \mathrm{C}$, detector temperature $230^{\circ} \mathrm{C}$; column flow $(\mathrm{He})$ $1.2 \mathrm{~mL} / \mathrm{min}$; temperature program for oven $60^{\circ} \mathrm{C}\left(5 \mathrm{~min}\right.$ isotherm) to $240^{\circ} \mathrm{C}$ at $5{ }^{\circ} \mathrm{C} / \mathrm{min}$, then $10 \mathrm{~min}$ isotherm at $240^{\circ} \mathrm{C}$. 


\subsection{Nuclear Magnetic Resonance}

All nuclear magnetic resonance (NMR) spectra were recorded on a Bruker AVANCE 400 Fourier transform spectrometer (Bruker, Wissembourg, France) operating at $400.132 \mathrm{MHz}$ for ${ }^{1} \mathrm{H}$ and $100.623 \mathrm{MHz}$ for ${ }^{13} \mathrm{C}$, equipped with a $5 \mathrm{~mm}$ probe, in $\mathrm{CDCl}_{3}$, with all shifts referred to internal TMS. The ${ }^{1} \mathrm{H}-\mathrm{NMR}$ spectra were recorded with the following parameters: pulse width (PW), $4.3 \mu \mathrm{s}$; relaxation delay $1 \mathrm{~s}$ and acquisition time $2.6 \mathrm{~s}$ for $32 \mathrm{~K}$ data table with a spectral width (SW) of $6000 \mathrm{~Hz} .{ }^{13} \mathrm{C}-\mathrm{NMR}$ spectra of the oil samples and fractions of $\mathrm{CC}$ were recorded with the following parameters: pulse width $=4 \mu \mathrm{s}$ (flip angle $45^{\circ}$ ); acquisition time $=2.7 \mathrm{~s}$ for $128 \mathrm{~K}$ data table with a spectral width of $25,000 \mathrm{~Hz}$ (250 ppm); CPD mode decoupling; digital resolution $=0.183 \mathrm{~Hz} / \mathrm{pt}$. Standard pulse sequences from Bruker Topspin ${ }^{\mathrm{TM}}$ (Bruker, Wissembourg, France) library were used for two-dimensional spectra. Gradient-enhanced sequences were used for the heteronuclear two-dimensional experiments. Spectra were processed via Mestrelab MestreNOVA software (version 12.0.0-20080).

\subsection{Identification of Individual Components}

Identification of individual components was carried out: (i) by comparison of their GC retention indices (RI) on polar and apolar columns with those of reference compounds [24,25]; (ii) on computer matching against commercial mass spectral libraries [26,27]; (iii) on comparison of the signals in the ${ }^{13} \mathrm{C}-\mathrm{NMR}$ spectra of the mixtures with those of reference spectra compiled in the laboratory spectral library, with the help of laboratory-made software $[15,16]$. This method allowed the identification of individual components of the essential oil at content as low as $0.4-0.5 \%$.

\subsection{Spectral Data}

(10ßH)-1 $\beta, 8 \beta$-Epoxy-cadina-4-ene (38): $\mathrm{C}_{15} \mathrm{H}_{24} \mathrm{O} ;{ }^{1} \mathrm{H}-\mathrm{NMR}\left(\mathrm{CDCl}_{3}, 400 \mathrm{MHz}\right)$ and ${ }^{13} \mathrm{C}-\mathrm{NMR}$ $\left(\mathrm{CDCl}_{3}, 100 \mathrm{MHz}\right.$ ) data: see Table 1. HREIMS: $\mathrm{m} / z 220.1821$ (calculated for $\mathrm{C}_{15} \mathrm{H}_{24} \mathrm{O}, 220.1822$ ); EI-MS $70 \mathrm{eV}, \mathrm{m} / \mathrm{z}$ (rel. int.): 220(13, $\left.\mathrm{M}^{\bullet+}\right), 178(15), 177(100), 159(34), 149(43), 135(16), 131(10), 121(19), 119(20)$, 110(56), 109(11), 107(31), 105(32), 97(67), 95(34), 93(41), 91(41), 81(26), 79(28), 69(78), 67(15), 65(11), 55(46), 53(14), 42(27), 41(58).

$(7 \alpha \mathrm{H})$-Germacrene $\mathrm{D}-8 \beta$-ol (52): $\mathrm{C}_{15} \mathrm{H}_{24} \mathrm{O} ;{ }^{1} \mathrm{H}-\mathrm{NMR}\left(\mathrm{CDCl}_{3}, 400 \mathrm{MHz}\right)$ and ${ }^{13} \mathrm{C}-\mathrm{NMR}$ $\left(\mathrm{CDCl}_{3}, 100 \mathrm{MHz}\right.$ ) data: see Table 2. HREIMS: $m / z 220.1823$ (calculated for $\mathrm{C}_{15} \mathrm{H}_{24} \mathrm{O}, 220.1822$ ); EI-MS $70 \mathrm{eV}, \mathrm{m} / \mathrm{z}$ (rel. int.): 220(1, $\left.\mathrm{M}^{\bullet+}\right), 202\left(34, \mathrm{M}^{\bullet+}-\mathrm{H}_{2} \mathrm{O}\right), 160(20), 159(100), 146(30), 145(30), 131(50)$, 121(25), 120(25), 119(50), 117(31), 109(21), 107(45), 105(68), 95(20), 93(65), 92(23), 91(88), 81(53), 80(20), 79(74), 77(47), 69(41), 67(35), 65(20), 55(43), 53(28), 43(61), 41(98).

$(7 \alpha \mathrm{H})$-Germacrene D- $\alpha$-ol (53): $\mathrm{C}_{15} \mathrm{H}_{24} \mathrm{O} ;{ }^{1} \mathrm{H}-\mathrm{NMR}\left(\mathrm{CDCl}_{3}, 400 \mathrm{MHz}\right)$ and ${ }^{13} \mathrm{C}-\mathrm{NMR}\left(\mathrm{CDCl}_{3}\right.$, $100 \mathrm{MHz}$ ) data: see Table 2. HREIMS: $m / z 220.1823$ (calculated for $\mathrm{C}_{15} \mathrm{H}_{24} \mathrm{O}, 220.1822$ ); EI-MS $70 \mathrm{eV}$, $m / z$ (rel. int.): 220(1, $\left.\mathrm{M}^{\bullet+}\right), 202\left(34, \mathrm{M}^{\bullet+}-\mathrm{H}_{2} \mathrm{O}\right), 160(20), 159(100), 146(30), 145(29), 131(48), 121(25)$, 120(24), 119(49), 117(30), 109(20), 107(44), 105(67), 95(20), 93(63), 92(21), 91(87), 81(51), 80(20), 79(72), 77(47), 69(38), 67(34), 65(19), 55(42), 53(26), 43(60).

Cadina-1(10),4-dien-8 3 -ol (56): $\mathrm{C}_{15} \mathrm{H}_{24} \mathrm{O} ;{ }^{1} \mathrm{H}-\mathrm{NMR}\left(\mathrm{CDCl}_{3}, 400 \mathrm{MHz}\right)$ and ${ }^{13} \mathrm{C}-\mathrm{NMR}\left(\mathrm{CDCl}_{3}\right.$, $100 \mathrm{MHz}$ ) data: see Table 3. HREIMS: $m / z 220.1823$ (calculated for $\mathrm{C}_{15} \mathrm{H}_{24} \mathrm{O}, 220.1822$ ); EI-MS $70 \mathrm{eV}$, $m / z$ (rel. int.): 220(1, $\left.\mathrm{M}^{\bullet+}\right), 202\left(12, \mathrm{M}^{\bullet+}-\mathrm{H}_{2} \mathrm{O}\right), 187(28), 174(7), 160(13), 159(100), 146(6), 145(11), 144(7)$, 134(10), 131(15), 129(6), 121(6), 119(21), 117(8), 115(6), 107(6), 105(19), 93(9), 91(19), 79(8), 77(10), 55(7), 43(9), 41(15).

Supplementary Materials: The following are available online, Figures S1-S24: 1D, 2D-NMR and EI-mass spectra of $(10 \beta \mathrm{H})-1 \beta, 8 \beta$-oxido-cadin-4-ene (38), (7 $\alpha \mathrm{H})$-Germacrene D-8 $\beta$-ol (52), (7 $\alpha \mathrm{H})$-Germacrene D-8 $\alpha$-ol (53) and Cadina-1(10),4-dien-8 $\beta$-ol (56).

Author Contributions: Conceptualization, D.A.K., J.B.B. and F.T.; methodology, D.A.K., T.A.Y. and Z.A.O.; software, D.A.K.; validation, J.J.B., F.T. and A.B.; formal analysis, D.A.K.; investigation, D.A.K., T.A.Y. and Z.A.O.; writing-original draft preparation, D.A.K., J.B.B., F.T. and J.C.; writing-review and editing, D.A.K., J.B.B., F.T. and J.C.; visualization, D.A.K., J.J.B. and A.B.; supervision, J.B.B. and F.T. All authors have read and agreed to the published version of the manuscript. 
Funding: This research received no external funding.

Acknowledgments: The authors gratefully acknowledge the Ministère de l'Enseignement Supérieur et de la Recherche Scientifique de Côte d'Ivoire for providing a research grant to D. A. Kambiré. We acknowledge J. Assi and $\mathrm{H}$. Téré for their valuable help in the plant identification. The authors are grateful to $\mathrm{H}$. Brevard and N. Barat (Robertet S.A.) for their technical assistance during HREIMS analysis.

Conflicts of Interest: The authors declare no conflict of interest.

\section{References}

1. Couvreur, T.L.P. Revealing the Secrets of African Annonaceae: Systematics, Evolution and Biogeography of the Syncarpous Genera Isolona and Monodora. Ph.D. Thesis, Wageningen University, Wageningen, The Netherlands, 2008; p. 294.

2. Aké, A.L. Flore de Côte d'Ivoire: Étude descriptive et biogéographique avec quelques notes ethno-botaniques. Thèse de Doctorat ès-Sciences Naturelles, Université d'Abidjan, Abidjan, Côte d'Ivoire, 1984; p. 1206.

3. Hocquemiller, R.; Cabalion, P.; Bruneton, J.; Cavé, A. Alcaloïdes des Annonacées XXIII. Alcaloïdes des écorces d'Isolona campanulata Engler et Diels. Plantes Méd. Phytothérapie 1978, 12, 230-234.

4. Okpekon, A.T. Étude chimique et biologique de plantes ivoiriennes utilisées en médecine traditionnelle en tant qu'antiparasitaires: Afromomum sceptrum K. Schum. (Zingiberaceae), Bridelia ferruginea Benth. (Euphorbiaceae), Isolona cooperi Hutch. \& Dalz. et Uvaria afzelii Sc. Elliot (Annonaceae). Ph.D. Thèse, Université Paris-Sud, France-Université de Cocody-Abidjan, Côte d'Ivoire, Paris, France, 2006; p. 283.

5. Kabran, A.F. Étude phytochimique de plantes ivoiriennes à activité antiparasitaire. Ph.D. Thèse, Université Paris-Sud, France-Université de Cocody-Abidjan, Côte d'Ivoire, Paris, France, 2013; p. 290.

6. Boti, J.B.; Koukoua, G.; N'Guessan, Y.T.; Muselli, A.; Bernardini, A.F.; Casanova, J. Composition of the leaf, stem bark and root bark oils of Isolona cooperi investigated by GC (retention index), GC-MS and ${ }^{13} \mathrm{C}-\mathrm{NMR}$ spectroscopy. Phytochem. Anal. 2005, 16, 357-363. [CrossRef]

7. Boti, J.B.; Yao, A.P.; Koukoua, G.; N'Guessan, Y.T.; Casanova, J. Components and chemical variability of Isolona campanulata Engler \& Diels leaf oil. Flavour Fragr. J. 2006, 21, 166-170. [CrossRef]

8. Kambiré, D.A.; Boti, J.B.; Ouattara, Z.A.; Yapi, A.T.; Bighelli, A.; Tomi, F.; Casanova, J. Leaf essential oil from Ivoirian Isolona dewevrei (Annonaceae): Chemical composition and structure elucidation of four new natural sesquiterpenes. Flavour Fragr. J. 2020. [CrossRef]

9. Kambiré, D.A.; Boti, J.B.; Ouattara, Z.A.; Yapi, A.T.; Nelly, B.; Bighelli, A.; Tomi, F. Chemical composition of root and stem bark essential oils from Ivorian Isolona dewevrei: Structural elucidation of a new natural germacrone. Nat. Prod. Res. 2020, accepted. [CrossRef]

10. Nea, F.; Kambiré, D.A.; Genva, M.; Tanoh, E.A.; Wognin, E.L.; Martin, H.; Brostaux, Y.; Tomi, F.; Lognay, G.C.; Tonzibo, Z.F.; et al. Composition, Seasonal Variation, and Biological Activities of Lantana camara Essential Oils from Côte d'Ivoire. Molecules 2020, 25, 2400. [CrossRef] [PubMed]

11. Kambiré, D.A.; Boti, J.B.; Yapi, A.T.; Ouattara, Z.A.; Paoli, M.; Bighelli, A.; Tomi, F.; Casanova, J. Composition and intraspecific chemical variability of leaf essential oil of Laggera pterodonta (DC.) Sch. Bip. ex Oliv. from Côte d'Ivoire. Chem. Biodivers. 2019, 17, e1900504. [CrossRef] [PubMed]

12. Kambiré, D.A.; Yapi, A.T.; Boti, J.B.; Ouattara, Z.A.; Tonzibo, Z.F.; Filippi, J.J.; Bighelli, A.; Tomi, F. Two new eudesman-4-ol epoxides from the stem essential oil of Laggera pterodonta from Côte d'Ivoire. Nat. Prod. Res. 2019. [CrossRef] [PubMed]

13. Kambiré, D.A.; Boti, J.B.; Filippi, J.J.; Tonzibo, Z.F.; Tomi, F. Characterization of a new epoxy-hydroxycarvotanacetone derivative from the leaf essential oil of Laggera pterodonta from Côte d'Ivoire. Nat. Prod. Res. 2019, 33, 2109-2112. [CrossRef] [PubMed]

14. Kambiré, D.A.; Yapi, A.T.; Boti, J.B.; Garcia, G.; Tomi, P.; Bighelli, A.; Tomi, F. Chemical composition of leaf essential oil of Piper umbellatum and aerial part essential oil of Piper guineense from Côte d'Ivoire. Nat. Prod. Commun. 2019, 14, 1-8. [CrossRef]

15. Tomi, F.; Bradesi, P.; Bighelli, A.; Casanova, J. Computer-aided identification of individual components of essential oils using carbon-13 NMR spectroscopy. J. Magn. Reson. Anal. 1995, 1, 25-34.

16. Ouattara, Z.A.; Boti, J.B.; Ahibo, A.C.; Sutour, S.; Casanova, J.; Tomi, F.; Bighelli, A. The key role of ${ }^{13}$ C NMR analysis in the identification of individual components of Polyalthia longifolia leaf oil. Flavour Fragr. J. 2014, 29, 371-379. [CrossRef] 
17. Gerhard, U.; Thomas, S.; Mortishire-Smith, R. Accelerated metabolite identification by 'extraction NMR'. J. Pharm. Biomed. Anal. 2003, 32, 531-538. [CrossRef]

18. Yapi, T.A.; Boti, J.B.; Attioua, B.K.; Ahibo, A.C.; Bighelli, A.; Casanova, J.; Tomi, F. Three new natural compounds from the root bark essential oil from Xylopia aethiopica. Phytochem. Anal. 2012, 23, 651-656. [CrossRef] [PubMed]

19. Weyerstahl, P.; Wahlburg, H.C.; Marschall, H.; Rustaiyan, A. New cadinene and bisabolene derivatives from the essential oil of Pulicaria gnaphalodes. Liebigs Ann. Chem. 1993, 1117-1123. [CrossRef]

20. Rustaiyan, A.; Monfared, A.; Masoudi, S. The Essential Oil of Ferula flabelliloba Rech. F. et Aell. J. Essent. Oil Res. 2001, 13, 403-404. [CrossRef]

21. Weyerstahl, P.; Marschall, H.; Wahlburg, H.C.; Cristiansen, C.; Rustaiyan, A.; Mirdjalili, F. Constituents of the essential oil of Pulicaria gnaphalodes (Vent.) Boiss. from Iran. Flavour Fragr. J. 1999, 14, 121-130. [CrossRef]

22. Lis, A.; Nazaruk, J.; Mielczarek, J.; Kalemba, D. Comparative Study of Chemical Composition of Essential Oils from Different Organs of Erigeron annuus (L.) Pers. J. Essent. Oil-Bear. Plants 2008, 11, 17-21. [CrossRef]

23. Cachet, T.; Brevard, H.; Chaintreau, A.; Demyttenaere, J.; French, L.; Gassenmeier, K.; Joulain, D.; Koenig, T.; Leijs, H.; Liddle, P.; et al. IOFI recommended practice for the use of predicted relative-response factors for the rapid quantification of volatile flavouring compounds by GC-FID. Flavour Fragr. J. 2016, 31, 191-194. [CrossRef]

24. König, W.A.; Hochmuth, D.H.; Joulain, D. Terpenoids and Related Constituents of Essential Oils. Library of MassFinder 2.1; Institute of Organic Chemistry: Hamburg, Germany, 2001.

25. Terpenoids Library Website. Available online: https://massfinder.com/wiki/Terpenoids_Library_List (accessed on 23 June 2020).

26. National Institute of Standards and Technology. PC Version of the Mass Spectral Library; National Institute of Standards and Technology: Norwalk, CT, USA, 2014.

27. Adams, R.P. Identification of Essential Oils Components by Gas. In Chromatography/Quadrupole Mass Spectroscopy; Allured: Carol Stream, IL, USA, 2001; p. 455.

Sample Availability: Samples of the compounds 38, 52 and 53 are available from the authors.

Publisher's Note: MDPI stays neutral with regard to jurisdictional claims in published maps and institutional affiliations.

(C) 2020 by the authors. Licensee MDPI, Basel, Switzerland. This article is an open access article distributed under the terms and conditions of the Creative Commons Attribution (CC BY) license (http://creativecommons.org/licenses/by/4.0/). 